\title{
THE ESSENCE AND CONTENT OF THE WORK OF THE DIAKONOS ACCORDING TO THE NEW TESTAMENT
}

\section{Gert Breed \\ North West University}

\begin{abstract}
The word dix́kovos is used for a large variety of persons in the New Testament. The question can be asked why this specific word was also used for some of the leaders (deacons) in congregations. The first step to answer this question, is to determine the essence and content of the work of a diókovos (not as leader) according to the New Testament. The aim of the article is a close study of the

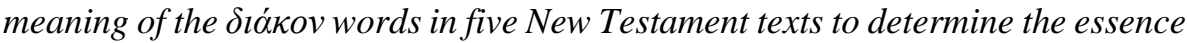

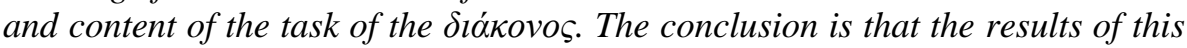
study cannot on their own determine the essence and content of the work of the deacon, but they lay the foundation for further study about the leader jiókovos (deacon). In further study it will be important to also look at the texts where the

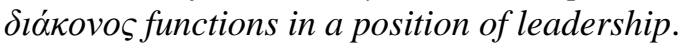

Key words: Deacon; Diakonos; Diakon- words; Congregational Ministry; New Testament

\section{Introduction}

The deacon can play a key role in the ministry plan of a congregation. This article is a

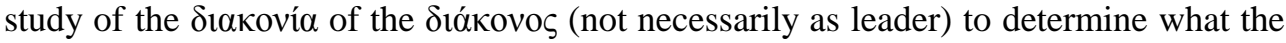

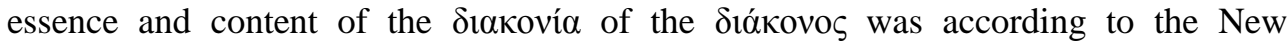
Testament. Acts 6 cannot be regarded as the description of the institution of the office of the deacon, and even if you want to take Acts 6 as such, it is uncertain what the essence and content of the seven's task were (Breed 2012; Pao 2011:129). The question arises what the source for determining the task of the deacon could be. The word "deacon" is

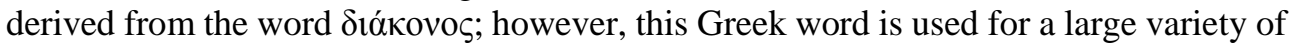
persons in the New Testament. It is widely accepted that its meaning as a technical term for a certain type of leader in the congregation, is most clearly stated in Philippians 1:1 and 1 Timothy 3 (Collins 2014:152, 153; Strauch 174-177; Aitchison 2003). Nowhere in the New Testament is the content of the work of the Siakóvor explicitly described (Latvus 2008). Why then, was the word Siókovos used to designate these specific leaders? A probable answer to this question is that the very essence of what the leaders were doing (their $\delta 1 \alpha \kappa o v i ́ \alpha$ ), is expressed by the semantic content of the $\delta$ iókov- word group (Van Klinken 1989:85, 59). Collins points out that a special meaning was attributed to the original Greek word Siókovos; it was therefore retained when the Bible

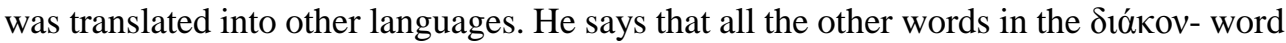
group were translated with words from the new language, but that "the word deacon was clearly a special case" (Collins 2002:6). 
The working hypothesis of this article is that the deacons were called so because they

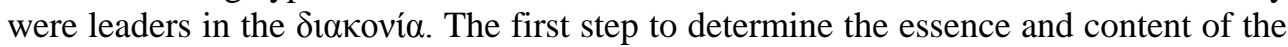
work of the deacon, could be to determine the essence and content of the work of a

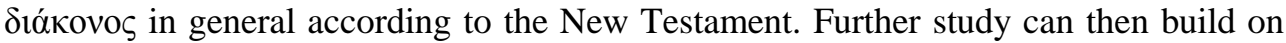

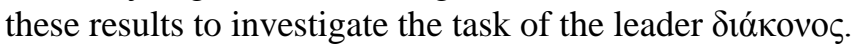

Parts of the New Testament where the $\delta$ iókov- word group is used, will be investigated to formulate a theory on the task of the $\delta$ iákovos. The history of the essence and content of the service of the deacon, as it was formulated in different times and denominations, cannot be discussed in the space of this article. ${ }^{1}$ The aim here is primarily

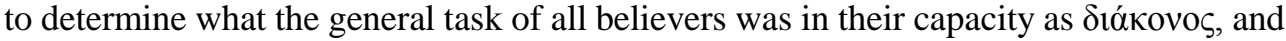

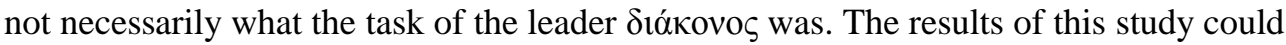

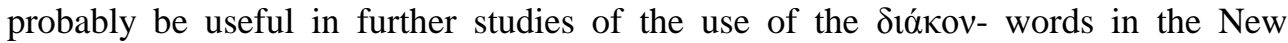
Testament to determine the task of leaders in the congregation. From the integration of such study results and the results of this study, it might be possible to give a clearer indication of the task of the deacon according to the New Testament and apply the findings in congregations today.

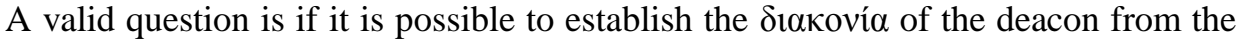
study of the $\delta$ iókov- word group. Avis (2009) and Shack (2011:51) motivate the possibility of accomplishing this goal. Avis $(2009: 4,5)$ says:

The New Testament provides neither precept nor precedent that fills in the content of diaconal ministry, what we do have is examples of the actual usage of Siókovwords in the Gospels, the Acts of the Apostles and the Pauline letters. How can the Church relate to this usage, how can it connect with it? ... To have integrity our own

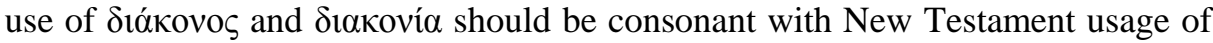
those terms; it should resonate with it and be empowered by it.

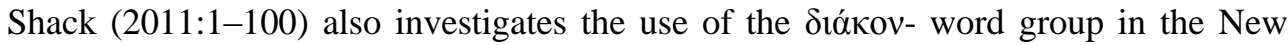
Testament to establish the task of the deacon today.

Louw and Nida's (1996: vi-Xx) approach to semantic domains will be discussed as

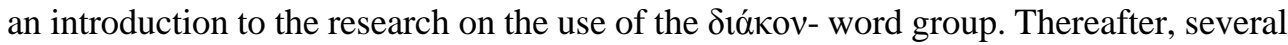
scriptural passages will be investigated. In the discussion of each scriptural passage, deductions will be made about what the original readers possibly had in mind when they called a person in the church a $\delta$ iókovo $\varsigma$ and what the essence and content of the work

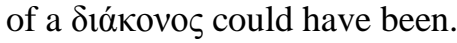

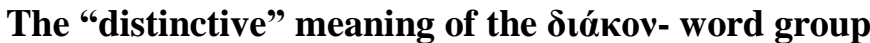

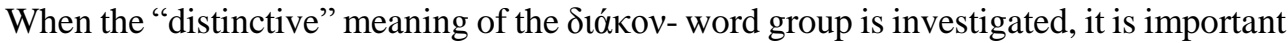
to take into account what Burton (1891:135) says:

The study of words is by no means the whole interpretation. No language, unless it be that of a mathematical formula or a logical definition, conveys in the words 
expressed all the thought which it represents in the mind of the speaker or even all that it is intended to create and actually does create in the mind of the intelligent hearer ... The interpreter who confines himself to mere word-study must often miss the richest and best of his author's thought.

It is important to state the insights of Louw and Nida into the use of words. They divide words into different semantic domains and explain the division as follows (Louw \& Nida 1996: vi-Xx):

The basis for the various semantic domains and subdomains consists of three major classes of semantic features: shared, distinctive, and supplementary. The shared features are those elements of the meaning of lexical items which are held in common by a set of lexical items. The distinctive features are those which separate meanings one from another and the supplementary features are those which may be relevant in certain contexts or may play primarily a connotative or associative role.

They give a further explanation of the use of words (Louw \& Nida 1996: vi-xx):

What is essential is that one does not confuse the meaning of a term with the particular reference which a term has in a specific context. For example, öpvis (4.38) may be defined as "any kind of bird, wild or domestic", but in Mt. 23:37 (the only occurrence of oppis in the New Testament) it probably refers to a hen, and therefore may be translated as such. But the meaning of ó $\rho v i \varsigma$ is not "hen" but "a bird of any kind, either wild or domestic", since it is used in Hellenistic and Classical Greek with precisely such a broad range of reference.

In similar fashion, $\theta \eta \dot{\chi \eta}$ (6.119) may be translated in John 18:11 as "sheath", since the context refers to putting a sword in its container. This does not mean that $\theta \eta \dot{\chi} \chi$ means "sheath", for $\theta \eta \dot{\chi} \eta$ designates "any receptacle into which an object is customarily placed for safekeeping".

The research results of John N. Collins and Anni Hentschel, who show that the $\delta$ iókov- word group does not primarily or always indicate humble service or charity, are widely accepted. Their finding is that the "distinctive" meaning (also called the

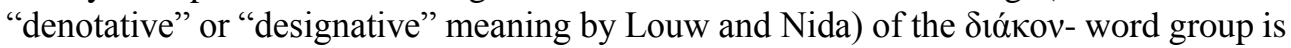
not humble service or charity, but "go-between", "envoy", "representative", or "spokesperson". Certain further possible meanings (shared and supplementary) of this word group in the New Testament should be excluded, according to Collins. His most prominent exclusions are that the word group does not indicate service done out of love for people and that it only refers to service that is performed by an ordained person in the church. In another article, I point out why these exclusions cannot be accepted and that the context should determine the semantic content (Breed 2017). This point of view

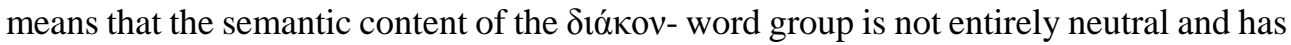
to be determined by the context.

This article is the first step towards determining the task of the deacon from the use

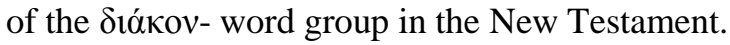




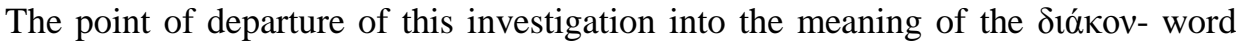
group is now explained. Every word has lexicographical semantic possibilities. A writer or a speaker can have one or more of these semantic possibilities in mind when using a word in a specific context. The reader or hearer can only establish from the context which one of these semantic possibilities the writer or speaker has in the mind. Writers can assign a unique semantic possibility (concept) to a certain word in their work (Breed 2017).

In this study, I will also look at the possibility of using the results of the exegesis of some passages where the diókov- word group is used to suggest a theory about the

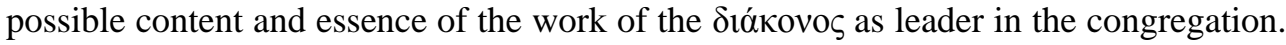
Five New Testament passages will be studied to determine different semantic

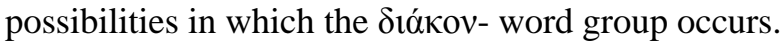

\section{Synthesis of the exegetical results}

I have done in-depth exegetical work on various New Testament passages where the $\delta ı \alpha ́ k o v-$ word group is used to establish (in some cases using macro- and microstructural analysis) the meaning of the words used in specific contexts (Breed and Breed 2010; Breed 2012; Breed 2014a; Breed 2014b; Breed 2015a; Breed 2015b; Breed 2016a; Breed 2016b; Breed 2016c; Breed 2017; Breed 2018). These results will be used to arrive at the closest possible answer to the question what the essence and content of the $\delta 1 \alpha \kappa o v i \alpha$

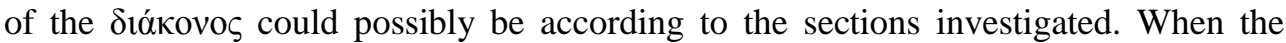
semantic possibilities in which the $\delta$ iókov- word group occurs, are taken into account, the research question of this part of the article can be formulated as follows: In view of the meaning of the $\delta$ iókov- word group, what semantic possibility or possibilities that are part of these concepts, are actualised in a specific New Testament section; and what

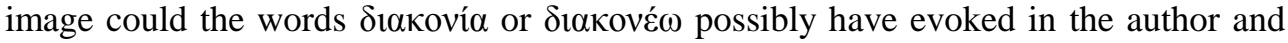

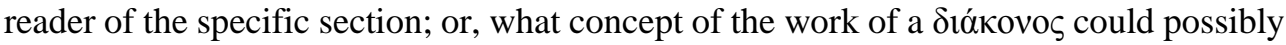
have lived in the minds of the authors and readers? From the answer to this research question, conclusions will be made about the possible essence and content of the

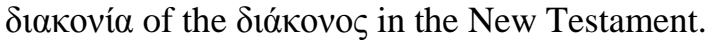

\section{Ephesians}

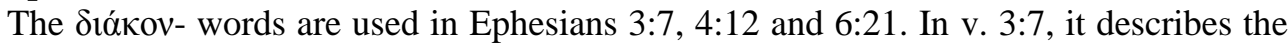

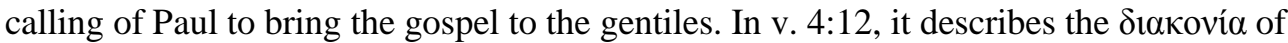
the believers and in v. 6:21, the work of Tychicus.

From my research on the meaning of the Siókov- word group in Ephesians (Breed 2014b), it has become clear that the triune God executes his eternal plan through the work of the Father, the Son and the Holy Spirit, making it possible for people to be freed from the power of the prince of evil and from their own sinful desires and live a new life in Christ (Breed 2014b; Floor 2011:471). The church came into existence through the fundamental work ( $\delta 1 \alpha \kappa o v i ́ \alpha)$ of the apostles. The purpose of the church is to exist for the praise and glory of God's grace and to make the wisdom of God known to all in this world (Eph. 2:7; 3:10). The purpose of the church can also be described as the continuous performance of the good deeds that God has prepared for believers as part of their lives (Eph. 2:10) (Hoehner 2002:348; O'Brien 1999:18). Through good deeds, the Lord can 
bring people to faith and make them part of the congregation (Eph. 3:7) (Breed 2014c:8; Breed 2015b).

The $\delta$ 1 $\alpha$ кoví $\alpha$ of all believers plays a vital role in the execution of God's plan to unite all things under the one head, Christ (Eph. 1:10) (Van Aarde 2014:210; Floor 2011:467480; Barnard 2009:168; Pester 2009). The $\delta 1 \alpha \kappa o v i ́ \alpha$ of the apostles was used by God to establish the church; the $\delta 1 \alpha$ koví $\alpha$ of the special services (offices) is used by God to equip believers for service (Van Aarde 2014:169). The $\delta 1 \alpha \kappa o v i ́ \alpha$ of believers is used by God to promote the church's growth to maturity (Eph. 4:12-16). The $\delta 1 \alpha \kappa o v i ́ \alpha$ of the church is the ministry of the grace that Christ measures out to every believer (Eph. 4:7) (Lincoln 1990:254). Christ gives special gifts (people) to the church to equip the members for

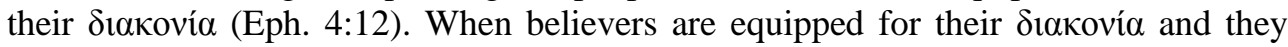
perform it, they grow in maturity to become increasingly like Christ and less vulnerable to the temptation of false doctrine (Eph. 4:15, 16) (Petrenko 2011:156, 157). As mature believers, they will talk to each other in truth and in love (Eph. 4:15; admonish and encourage). The edification process is characterised by love. When believers use their gifts, the congregation is bound together in a unity according to the plan of God, and God reveals his wisdom and the glory of his grace to and through them (Van Aarde 2014:144). The imperative that demands a certain life-style from the believers (Eph. 4:17) is based on knowledge of Christ (the indicative of the work of the triune God). The equipment of believers to perform service enables them to break with the old human being, to renew their thinking, and to make the new human being a reality in their words and deeds (Eph. 4:17-24) (Mbennah 2016:116-118).

The essence of the $\delta 1 \alpha \kappa o v i \alpha$, according to Ephesians, could be the execution of God's

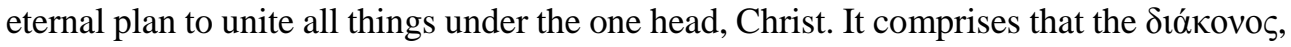
who has received Christ's grace, must in turn minister it to others through the works of $\delta 1 \alpha \kappa o v i ́ \alpha$ with a view to the edification and growth to maturity of the church.

The content of the $\delta$ i $\alpha$ Koví $\alpha$ could be the practical good works that are performed. It could comprise the fulfilment of unique functions in the congregation, for which everyone receives gifts, the equipment provided by the leaders, telling the truth to each other in love, and living in a way that is worthy of their calling.

\section{The Gospel according to John}

The $\delta$ iakov- words are used three times in John 12. Chapter 12 can be seen as a transition from the description of Jesus' work in public (Jn. 1-12) to his work focused on the disciples (Jn. 13-21). In chapter 12, the contrast between those who believe, follow and serve Jesus, and those who do not believe, is accentuated.

Two of my articles deal with the use of the Siókov- word group in John (Breed 2014b; Breed 2015a).

\section{$\triangle$ uxkoví understood as making Jesus and the Father visible}

In John, a two-tiered narrative can be detected. One level of the narrative deals with what can be seen and experienced by all people through their senses. The other level of John's narrative deals with what is implied by the visible and experiential reality, but is not observable to all people (Breed 2015a:3, 4). Jesus came to make this hidden truth known through the words of the Father, which He_-Jesus_-spoke, and through the deeds He 
did (Breed 2015a:3, 4; Bruner, 2012:734). In this way, He revealed the Father, whom no one except Jesus has seen yet. Only those who are reborn through the Spirit, can observe, understand and believe this revelation. The others persevere in their unbelief (Köstenberger \& Swain 2008:164). Those who believe, participate in the unity that is found between the Father and the Son (Breed 2015a:4; Peterson 2009:59). They become

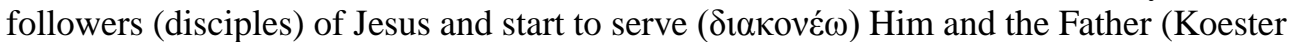
2008:129, 130). Those who serve Jesus, follow Him by doing his work and speaking his words (Jn. 12:26). In and through their service, Jesus and the Father are revealed to people who see and hear them (Breed 2015a:6; Bruner 2012:741; Van der Merwe 1997:343; Du Rand 1991:318).

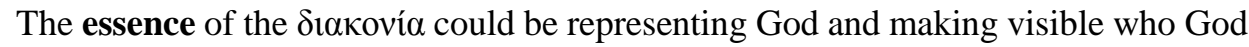

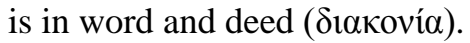

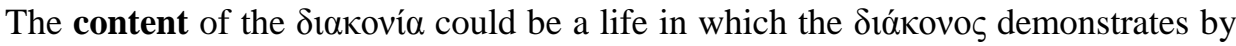
his deeds and words, through the guidance of the Holy Spirit, the obedience of Jesus to the Father and his love.

\section{John 12 Diakonia and following Jesus}

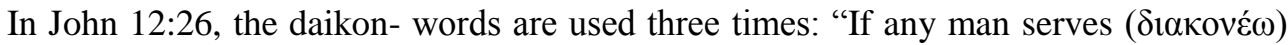

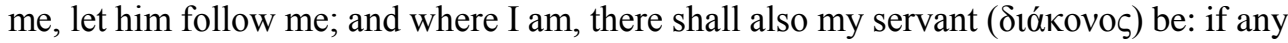

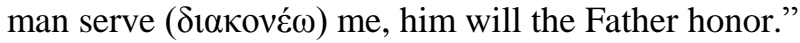

John 12 places the $\delta$ iókovo suffering and death, resurrection and ascension of Jesus (Anderson 1999:42; Van der

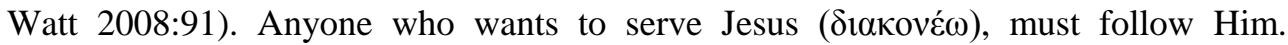
Following Jesus essentially means to accept the task that Jesus received from the Father,

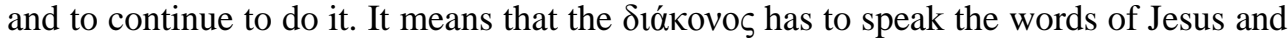
to do the deeds of Jesus (MacArthur 2005:11; Thomas 2004:80; Van der Watt 2008:89; Von Wahlde 2010:555). In John 12, following Jesus is linked to the death of Jesus, the

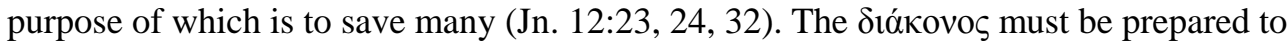
follow Jesus to death (Jn. 12:25). They must be willing to lose their life to regain it. In

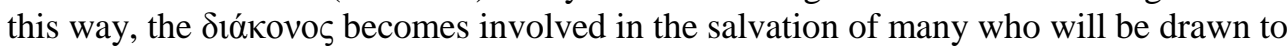
Jesus through their words and deeds (Van der Watt 2008:94). Two promises are given to those who serve Jesus and therefore follow Him. They will be where Jesus is, which means, in their relationship with the Father and the Son, they will be in the position where Jesus is in his relationship with the Father (Breed 2014c:4). The second is that the Father will honour them. The suffering and the dishonour they experience because of their $\delta 1 \alpha \kappa o v i \alpha$, will stand in contrast to the honour they will receive from the Father. The $\delta$ óxovo $\varsigma$ glorifies Jesus and the Father, and is glorified by Jesus and the Father (12:26) (Neyrey 2007:214).

The essence of $\delta 1 \alpha$ kovía could be following Jesus where He is waiting, in anticipation of the honour the Father bestows.

The content of the $\delta$ iakovía could be following Jesus by doing practical deeds with a view to leading people to Jesus, even if it requires them to sacrifice their life. 


\section{Mark 8-10 Diakonia and compassion}

In an article on the use of the Siókov- word group in Mark 10:42-5, I argue that Mark guides his leaders to understand $\delta 1 \alpha \kappa o v i ́ \alpha$ as work done with an open and compassionate attitude towards other people, even to those who are not entitled to it (Breed 2017; see also Sabin 2005:87-89). In Mark 8-10, Jesus is preparing his disciples with great patience to act as leaders (Breed 2017). The most important attitude they as leaders have to adopt, is not being rulers, but servants. This teaching stands in contrast to the attitude of the world's rulers, who reign over their subjects (Wilcox 1996:175). Trusting that in God they are first, Jesus' followers can be the servants of all and become the slaves of all (Jn. 10:43, 44). In this way, they follow Jesus, who did not come to be served, but to serve, and gave his life as ransom for many (Jn. 10:45) (De Mingo Kaminouchi 2003:206). Diaconal service stands in the light of the reconciliation that Jesus brought about by the ransom He paid.

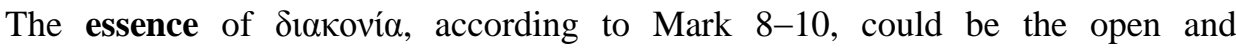
compassionate attitude found in a diókovos, who, as an envoy of God, does not want to rule over others, but wishes to serve them.

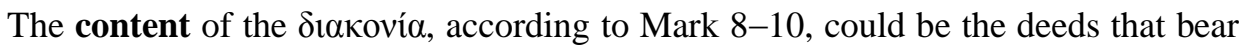
testimony to openness and compassion and do not seek to rule over others.

\section{Peter 4 and 5}

The $\delta$ iókov- word group is used in 1 Peter 4:10, where Peter encourages his readers to

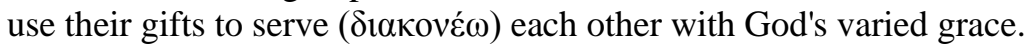

Peter writes a pastoral letter to people who endure intense hardships (Breed 2016a:5). He guides them with his letter to live in the midst of rejection and persecution according to their new identity and calling as renewed people (Fagbemi 2009). To achieve this, they must show mutual friendliness and hospitality (1 Pet. 4:9) (Green 2007:145, 146). They must understand that they are managers of God's multi-colored grace by serving each other according to the gifts each of them has received (1 Pet. 4:10). Those who received gifts of teaching, have to speak the words of God. Those who have received the

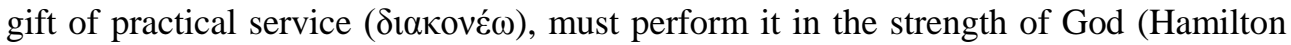
2010:523). The elders must take care of the congregation like shepherds and supervise them with the attitude that Christ taught his disciples (1 Pet. 5:1-3). The whole congregation must be humble under the powerful hand of God and serve each other in anticipation that God will exalt them at the right time (1 Pet. 5:4-6) (Breed 2016a:6).

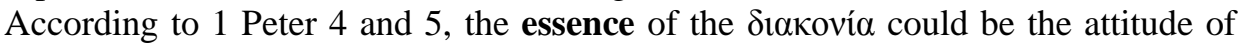
openness found in people who humbly take care of others and do not seek their own interests or rule, but act in anticipation of the exaltation that God bestows.

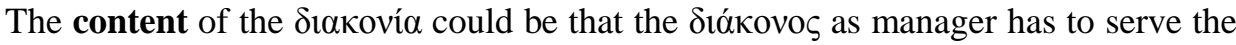
multi-coloured grace of God to the congregation to enable them to persevere in the midst of hardships.

\section{Corinthians 12}

I also investigated 1 Corinthians 12 , focusing on ministry to children as representatives of groups in the congregation who could possibly be "outsiders" (Breed 2016c:274300). 


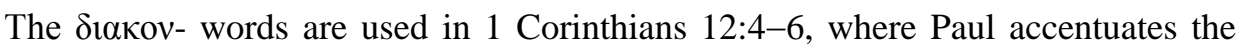
variety of gifts, services ( $\delta 1 \alpha \kappa o v i \alpha)$ and activities that are assigned by the one triune God who works all things in everyone through the $\delta$ isoví $\alpha$ of those who use their gifts.

The work of the Holy Spirit takes a central position in 1 Corinthians 12 . He brings people to the confession that Jesus is Lord (1 Cor. 12:3). This confession serves as a measure whether someone is led by the Spirit (1 Cor. 12:2, 3). The one God (Father, Son and Holy Spirit) distributes the gift and instructs them to perform $\delta 1 \alpha \kappa o v i ́ \alpha$, resulting in the powerful work that creates everything in everyone when the gifts are used to perform diaconal service (Thiselton 2000:931). The $\delta 1 \alpha \kappa o v i ́ \alpha$ is performed to edify the body of Christ. The diversity found in the body is bound together in unity by the $\delta$ akoví $\alpha$ that each member enacts and receives. The apostles, prophets and preachers occupy a special place in activating the gifts for service (1 Cor. 12:11) (Kinnaman 2011:13).

The fact that the unity of the body is served because all members sees themselves as necessary yet dependent members of the body, is strongly emphasised in 1 Corinthians 12. The relationship between gifts, service and the powerful work of God, through which everything in everyone is brought into existence, is also singled out. When members use their gifts to perform service ( $\delta 1 \alpha \kappa o v i ́ \alpha$ ), God works in a powerful manner to bring about rebirth, faith, diligence and commitment in people and congregations (Breed 2016c:287291; Goede 2004:183, 184).

The essence of $\delta 1 \alpha \kappa o v i ́ \alpha$, according to 1 Corinthians 12 , could be that it flows forth from the fact that the Spirit gives gifts and that God works powerfully through these gifts to bring about everything in everyone. The $\delta$ iкoví $\alpha$ is built on the confession that Jesus is Lord, as opposed to a life in the power of mute idols. $\Delta$ takoví $\alpha$ includes everyone who is part of the congregation.

The content of the $\delta 1 \alpha$ Koví $\alpha$ could be active in intimate mutual involvement between members of the congregation, the utilisation of gifts to edify the congregation and the mutual reception of the ministry.

\section{Conclusion}

By investigating the meaning of the Siókov- word group in several New Testament texts,

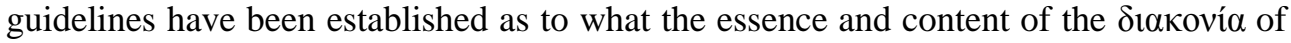
the Siókovos in the New Testament could have entailed. These results can lay the foundation for further research into the task of the deacon as derived from the $\delta$ iókovword group in the New Testament. However, further research will have to be done on

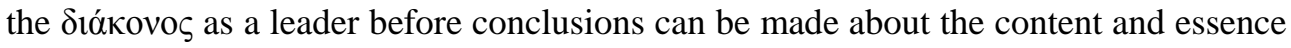
of the task of the deacon in the church today. It will be important to compare the different

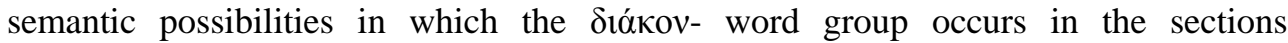
investigated to establish if different authors use the word with concurring semantic possibilities. In such an analysis, the sections in which the same semantic possibility is actualised by the authors, can possibly be combined to identify the different concepts

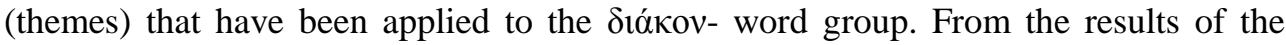
research done on the $\delta 1 \alpha \kappa o v i ́ \alpha$ of the $\delta$ iákovo $\varsigma$ (in this article) and the results of research

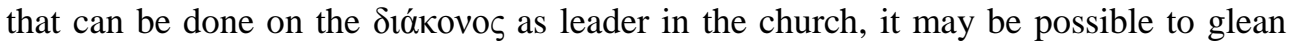
guidelines for the work of the deacon today. 


\section{BIBLIOGRAPHY}

Aitchison, Ronnie. 2003. The ministry of a deacon. Werrington: Epworth.

Anderson, Paul N. 1999. The having-sent-me Father: Aspects of agency, encounter, and irony in the Johannine Father-Son relationship, Semeia 85.

Avis, Paul. 2009. Wrestling with the diaconate, Ecclesiology 5(1).

Barnard, Jody A. 2009. Unity in Christ: The purpose of Ephesians. The Expository Times 120(4):168. Online: https://doi.org/10.1177/0014524608099799.

Breed, G. and Breed, D.G. 2010. Besinning oor die diakonale dienswerk na aanleiding van Handelinge 6:1-7, In die Skriflig 44(3/4):627-653.

Breed, Gert. 2012. Nuut gedink oor die wese en inhoud van die dienswerk van die diaken/Thinking new on the essence and content of the service of the deacon, HTS Teologiese Studies/Theological Studies 68(1):1-8. Online: http://dx.doi.org/ 10.4102 /hts.v68i1. 1059.

Breed, G. 2014a. The diakonia of Practical Theology to the alienated in South Africa in the light of 1 Peter, Verbum et Ecclesia 35(1). Online: Art. \#847, 9 pages, http://dx.doi.org /10.4102/ve.v35i1.847.

Breed, G. 2014b. The meaning of the diakon word group in John 12:26 applied to the ministry in congregations, Verbum et Ecclesia 35(1). Online: Art. \#844, 8 pages, http://dx.doi. org/10.4102/ve.v35i1.844.

Breed, Gert. 2014c. 'n Kritiese blik op missio Dei in die lig van Efesiërs, In die Skriflig 48(2):1-9. Online: http://dx.doi.org/10.4102/ids.v48i2.1707.

Breed, Gert. 2015a. Finding guidelines on social change in the two-tiered narrative and $\delta 1 \alpha \kappa o v i ́ \alpha$ in the Gospel of John, HTS Teologiese Studies/Theological Studies 7(2):1-7. Online: http://dx.doi.org/10.4102/hts.v71i2.2666.

Breed, Gert. 2015b. Ministry to the congregation according to the Letter to the Ephesians, Acta Theologica 35(1):37-58. Online: http://dx.doi.org/10.4314/ actat.v35i1.3.

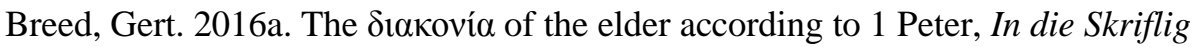
50(3):1-7. Online: http://dx.doi.org/10.4102/ids.v50i3.2102016.

Breed, Gert. 2016b. A social movement against corruption in the footsteps of Jesus' $\delta 1 \alpha$ Koví $\alpha$ according to Matthew. In F.P. Kruger and B.J. de Klerk (eds), Corruption in South Africa's liberal democratic context: Equipping Christian leaders and communities for their role in countering corruption. Durbanville: Aosis, pp. 160-184.

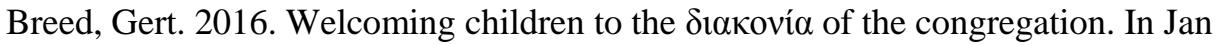
Grobbelaar and Gert Breed (eds), Theologies of childhood and the Children of Africa, Durbanville: Aosis, pp. 274-300. Online: http://books.aosis.co.za/ index.php/ob/catalog/book/34.

Breed, Gert. 2017. Diakonia: In conversation with John N Collins, Ecclesiology 13(3):349-368. Online: https://www.researchgate.net/publication/320073048_ Diakonia_In_Conversation_with_John_N_Collins.

Breed, Gert. 2018. The diakon- word group in the New Testament and congregational ministry. PhD dissertation, Radboud University, Nijmegen. 
Bruner, Fredrick Dale. 2012. The Gospel of John: A commentary. Grand Rapids: Eerdmans.

Burton, Ernest Dewitt. 1891. The study of New Testament words, The Old and New Testament Student 12(3). Online: http://www.jstor.org/stable/3157789.

Collins, Joan N. 2002. Deacons and the church: Making connections between old and new. Harrisburg: Gracewing.

Collins, Joan N. 2014. Diakonia studies: Critical issues in ministry. Oxford: Oxford University Press.

Crijns, Hub, et al. (eds). 2011. Diaconie in beweging: Handboek diaconiewetenschap. Kampen: Kok.

De Mingo Kaminouchi, Alberto. 2003. But it is not so among you: Echoes of power in Mark 10:32-45. New York: T\&T Clark.

Du Rand, J.A. 1991. Perspectives on Johannine discipleship according to the farewell discourses, Neotestamentica 25(2):311-325.

Fagbemi, Stephen Ayodeji A. 2009. Living for Christ in a hostile world: The Christian identity and its present challenges in 1 Peter, Transformation: An international journal of Holistic Mission Studies 26(1):1-12.

Floor, L. 2011. Een blauwdruk voor de toekomst: Efeziërs 1:9-10, In die Skriflig 45(2\&3):467-480.

Goede, H. 2004. Die voorstelling en die verteenwoordiging van die liggaam-metafoor in 1 Korintiërs 12:1-31, Acta Patristica et Byzantina 15:184-211.

Hamilton, James M. Jr. 2010. God's glory in salvation through judgement: A Biblical theology. Wheaton: Crossway.

Green, Joel B. 2007. 1 Peter. Grand Rapids: Eerdmans.

Hoehner, Harold Walter. 2002. Ephesians: An exegetical commentary. Grand Rapids: Baker Academic.

Koester, Craig R. 2008. The Word of life: A theology of John's Gospel. Grand Rapids: Eerdmans.

Köstenberger, Andreas J. and Swain, Scott R. 2008. Father, Son and Spirit: The Trinity and John's Gospel. Downers Grove: InterVarsity Press.

Latvus, Kari. 2008. The paradigm challenged: A new analysis of the origin of diakonia, Studia Theologica 62:152.

Lincoln, Andrew T. 1990. Ephesians. Dallas: Word Incorporated.

Louw, Johannes P. and Nida, Eugene Albert. 1996. Greek-English lexicon of the New Testament: Based on semantic domains, electronic ed. of the $2^{\text {nd }}$ ed. New York: United Bible Societies.

MacArthur, John. 2005. Hard to believe: The high cost and infinite value of following Jesus. Nashville: Thomas Nelson.

Mbennah, Emmanuel D. 2016. The goal of maturity in Ephesians 4:13-16, Acta Theologica 36(1):110-132. Online: http://dx.doi.org/10.4314/actat.v36i1.7.

McKee, Elsie Anne. 1989. Diakonia in the classical Reformed tradition and today. Grand Rapids: Eerdmans.

Neyrey, Jerome H. 2007. The Gospel of John. New York: Cambridge University Press. O'Brien, Peter T. 1999. The Letter to the Ephesians. Grand Rapids: Eerdmans.

Olson, Jeannine E. 2005. Deacons and deaconesses through the centuries. Saint Louis: Concordia. 
Pao, David W. 2011. Waiters or Preachers: Acts 6:1-7 and the Lukan table fellowship motif, Journal of Biblical Literature 130(1):127-144.

Pester, John. 2009. The role of revelation in the fulfilment of the economy in God in Ephesians, Affirmation and Critique 14(2):29-42.

Peterson, David G. 2009. The Acts of the Apostles. Grand Rapids: Eerdmans.

Petrenko, Esther. 2011. Created in Christ Jesus for good works: The integration of soteriology and ethics in Ephesian. Milton Keynes: Paternoster.

Sabin, Marie Noonan. 2005. The Gospel according to Mark. Collegeville: Liturgical Press.

Shack, Jennifer. 2011. A comparison between the diaconates of Lutheran Church: Canada and the New Testament. Master's thesis, Concordia University College of Alberta, Edmonton.

Strauch, Alexander. 2003. Biblical leadership: An urgent call to restore Biblical church leadership. Littleton: Lewis and Roth.

Thiselton, Anthony C. 2000. The First Epistle to the Corinthians: A commentary on the Greek text. Grand Rapids: Eerdmans.

Thomas, John Christopher. 2004. In John 13 and the Johannine community. London: T\&T Clark.

Van Aarde, Timothy. 2014. The missional purpose of the Letter to the Ephesians. Doctoral dissertation, North-West University, Potchefstroom.

Van der Merwe, Dirk G. 1997. Towards a theological understanding of Johannine Discipleship, Neotestamentica 31(2).

Van der Watt, J. 2008. Johannine style: Some initial remarks on the functional use of repetition in the Gospel according to John, In die Skriflig 42(1).

Van Klinken, Jaap. 1989. Diakonia: Mutual helping with justice and compassion. Kampen: Kok.

Von Wahlde, Urban C. 2010. The Gospel and letters of John, vol. 2: Commentary on the Gospel of John. Grand Rapids: Eerdmans.

Wilcox, M. 1996. On the ransom saying in Mark 10:45c, Matthew 20:28c. In H. Lichtenberger (ed.), Geschichte, Tradition, Reflexion: Festschrift für Martin Hengel zum 70 Geburstag. Tübingen: Mohr Siebeck. 